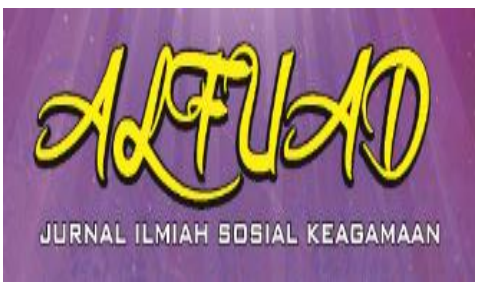

ALFUAD JOURNAL, 5 (1), 2021, (51-58)

\title{
Impact of Disclaimer due to Covid-19 on The Religious Value of Official Workers
}

\author{
Siti Zakiyatul Fikriyah*) \\ Pesantren Riset Al-Muhtada Semarang Jawa \\ Tengah \\ E-mail: sitizakiyatulfikriyah5@gmail.com
}

\section{Khoirul Mumtahanah}

Pesantren Riset Al-Muhtada Semarang Jawa Tengah

E-mail: khoirul.mumtahanah@gmail.com

\section{Khasiatun Amaliyah}

Pesantren Riset Al-Muhtada Semarang Jawa Tengah

E-mail:

khasiatunamaliyah12@students.unnes.ac.id

*) Corresponding Author

\begin{abstract}
The Covid-19 virus is one type of infectious disease or infectious disease that emerged in Wuhan, China in December 2019. And began to spread in Indonesia in March 2021. The increasing number of positive cases and deaths due to Covid-19 has led the government to implement several policies, namely restrictions on Large-Scale Social Affairs (PSBB) and working from home. This policy has a very big impact on employers because they experience enormous losses so that company leaders carry out layoffs (layoffs) on a large scale or on a large scale. The impact of the termination of employment is felt directly by the workers concerned. And social changes began to occur in workers who were laid off (changes in religiosity), such as what happened in Dongos Village, Kedung District, Jepara Regency. This study aims to see the impact and influence factors of layoffs due to Covid-19 on the religious level of workers who were laid off and who were not laid off. The method used is a combined research approach (quantitative and qualitative), using a questionnaire and direct interviews. The results obtained indicate that layoffs due to Covid-19 affect the level of religiosity of laidoff workers. Moreover, there is a difference in the level of religiosity between workers who were laid off and those who were not. The factors that influence the impact of layoffs due to Covid-19 on the level of worker religiosity are 1) Ideological, 2) Ritualistic, 3) Expressive, and 4) Consequences.
\end{abstract}

Keywords: Covid-19, Religiosity, Work Termination

\section{INTRODUCTION}

Covid-19 or so-called Coronavirus19 which was originally in 2019 was named SARS.CoV.2 (type of infectious disease). WHO statement on March 11, 2020 which stated that Covid-19 was declared a global epidemic or pandemic. Indonesia also entered and became one of these countries. Corona virus is a new epidemic that can cause disease in animals as well as humans. There are several types of corona virus that can cause infection of the human respiratory tract, it is characterized by coughs and colds. More serious levels include Middle East Respiratory Syndrome (MERS) and Severe Acute Respiratory Syndrome (SARS).

In Indonesia, patients with the corona virus began to be detected in early March 2020. Although it seemed the 
slowest in spreading the corona virus to Indonesia, as of April 18, 2020, Indonesia had confirmed that there were 6,248 positive cases of Covid-19 and 631 cures (Sugiyanto et al, 2020: 229). Just one month into Indonesia, there have been thousands of confirmed cases of Covid-19 sufferers. Efforts are being made to implement health and civilized protocols, universities and workplaces that have the potential to spread Covid-19 are eliminated. This means that in this case there is a learning system from home and working from home or WFH (Work From Home). Presented by President Joko Widodo at the Bogor Palace; Worship must be done in their respective homes, in addition to all schools. Sunday (15/03) Jokowi said that as an effort to minimize the spread of Covid-19, all forms of activity (study, work, and other activities) were carried out at home (Kompas.com, 2020)

The impact that is very influential on almost all circles of society is the economic impact in Indonesia. This is because various companies and entrepreneurs are required to rack their brains to find ways to avoid losses caused by the spread of this pandemic (Romlah, 2020: 214). Not only a few, even many of the companies are facing this difficult situation, so it requires an immediate decision. One of these decisions is
Termination of Employment (PHK). According to Anwar (2020: 174) Termination of employment is a decision that will not only be detrimental to the workers but also to the company itself. As stated in Law (UU) No. 13 of 2003 concerning Employment that Termination of Employment is the last step that can be taken. Also in Law Number 13 of 2003 Article 151 paragraph (1) also states that employers, workers, laborers, and the government, with all efforts must try to prevent layoffs from happening (Prajnaparamitha \& Mahendra, 2020: 318). So that the Termination of Employment is a last resort to reduce major losses of course.

Covid-19 has also had a significant impact on the religious field of Indonesian society. President Joko Widodo stated that in order to minimize the spread of Covid19, all forms of activity that can cause Covid-19 transmission must be carried out at their respective homes, especially in matters of worship. This is in line with the regulations issued by the government regarding the recommendation of religious people to carry out worship in their respective homes. The regulation was also strengthened and supported by the Fatwa of the Indonesian Ulema Council (MUI), Fatwa of the Indonesian Ulema Council Number: 14 of 2020 concerning the Implementation of Worship in Situations 
of an outbreak which is believed to be able to break the chain of the spread of the Covid-19 virus. According to Marx, who was once quoted by Hakim, religion is an opium for society, because religion will influence people not to overcome their socio-economic difficulties. Because of religious teachings, the people accept the fate or calamity that is currently befalling them (Rumahsosiologi.com, 2020).

Based on the description above, this research is focused on Kedung District, Jepara Regency, which is the place for mass layoffs (PHK) from various parts of Indonesia. Jepara Regency is a district that has many industrial companies and factories that employ workers. Many workers come from Jepara Regency itself, especially in Kedung District. Reporting from BPS Jepara Regency, industrial companies are divided into 4 groups, where each group has a minimum of 100 workers (bps.go.id, 2020) and there are 59 factories in Jepara Regency. In previous studies, no one has mentioned religious values in terms of changing the behavior of workers. Therefore, this study will focus on the religious values of workers who have been laid off and laid off, either before or after. Thus, it will be able to answer the formulation of the problem related to how the impact of Covid-19 on the level of religiosity of workers who were laid off in Dongos Village, Kedung
District, Jepara Regency. And what factors influence the impact of Covid-19 on the religiosity of laid-off workers and workers who were not laid off due to Covid-19 in Dongos Village, Kedung District, Jepara Regency.

\section{METHOD}

This research belongs to research that uses the mix method or an approach in research methodology that combines, mixes, or connects two types of methods at once, namely qualitative and quantitative (Fitri and Nik Haryati, 2020: 36). Using documentation techniques, interviews, questionnaires, and literature studies.

Literature studies come from several sources, both books, print media, electronic media and journals. Interviews were conducted with workers who were laid off and not laid off, this was done to find the results of this type of qualitative research. Meanwhile, for quantitative research, questionnaires were distributed to workers who were laid off and those who were not. The data analysis itself is carried out in stages starting from preparing the type of data, analyzing the data, then drawing conclusions and presenting the data.

The data are presented and presented in a descriptive analysis because this research is a combined research. To test the validity of the data, a validity test 
was carried out on each variable (Variable X: Effect of Covid-19, Variable Y1: Workers who were laid off, and Variable Y2: Workers who were not laid off). Then proceed with the test of reliability, normality, homogeneity, and hypotheses. In addition, researchers also conducted direct observations of the behavior of workers who were laid off due to Covid19.

\section{RESULT AND DISCUSSION}

Covid-19 has almost spread throughout Indonesia, even almost all countries. This situation caused the government to impose a policy in several areas, namely Large-Scale Social Restrictions (PSBB) and working from home. This, of course, has a huge impact on entrepreneurs who have suffered huge losses due to the policy, so that the top executives carry out mass or large-scale layoffs.

The impact of the termination of employment is certainly felt by the workers concerned. Not only in one area, but almost all companies in Indonesia have terminated their employment relationship with their employees. Like the termination of employment that occurred in Dongos Village, Kedung District, Jepara Regency. The majority of people's jobs in Dongos Village are factory workers, so that when a layoff occurs in Dongos Village, the impact is felt. Starting from the poor economy of the community, and the level of religiosity.

The Impact of Termination of Employment (PHK) Due to Covid-19 on the Level of Religiosity of Laid-off Workers and Workers Not Laying Off

The Covid-19 pandemic has had an impact on all aspects of human life, including workers. Dongos Village, Kedung District, Jepara Regency is one of the areas affected by the impact where there are 120 workers who have the potential to be laid off. In this study, respondents who became the object of research were 15 workers who were laid off and 15 workers who were not laid off. The number is based on the calculation of $25 \% \times 120=30$ people. From the research data obtained, it shows that the data is valid data with a validity value of $100 \%$. The data is presented in table 1 .

\begin{tabular}{|rl|r|l|}
\hline & & \multicolumn{1}{|c|}{ N } & \multicolumn{1}{l|}{$\%$} \\
\hline Cases & Valid & 15 & 100. \\
& & 0 & 0 \\
& Excluded & 15 & .0 \\
& Total & & 100. \\
& & & 0 \\
\hline
\end{tabular}

The presence of the Covid-19 pandemic in Indonesia is closely related to the dimensions of religiosity, especially the dimensions of consequences. The growing 
presence of Covid-19 has brought about various crises, including health, political, economic, and trust crises. Hamali (2001) revealed that the crisis that hit the community had also penetrated religious values which made the relationship between religion and culture even more fragile. This makes religious values increasingly fade in their attitudes and actions (Hamali, 2001).

This study was aimed to determine the impact of Covid-19 on the level of religiosity of laid-off and non-layoffed workers in Dongos Village, Kedung District, Jepara Regency. To find out, several tests were carried out using SPSS, namely the simple linear regression test and the Paired Sample Test.

Table 2. Simple Linear Regression Test

\begin{tabular}{|c|c|c|c|c|}
\hline Model & $\mathrm{R}$ & $\mathrm{R}$ Square & $\begin{array}{c}\text { Adjusted } \mathrm{R} \\
\text { Square }\end{array}$ & $\begin{array}{c}\text { Std. Error of } \\
\text { the Estimate }\end{array}$ \\
\hline & 0,726 & 0,671 & 0,632 & 1,42332 \\
\hline
\end{tabular}

Simple linear regression test is intended to determine the effect of variable $\mathrm{X}$ on variable $\mathrm{Y} 1$. From the results of this test, a correlation index of 0.671 was obtained. If consulted with table 2 , the number of $\mathrm{R}$ Square (0.671) is between

\begin{tabular}{|r|r|r|r|r|}
\hline & $\begin{array}{c}\text { Levene } \\
\text { Statistic }\end{array}$ & df1 & df2 & \multicolumn{1}{|c|}{ Sig. } \\
\hline Y1 & 4.012 & 3 & 6 & .070 \\
Y2 & .11 & 3 & 6 & .945 \\
\hline
\end{tabular}

$0.40-0.70$ which means it is included in the category of moderate or sufficient correlation. From the results of these calculations, it shows that there is a significant influence between the impact of layoffs caused by Covid-19 and the level of religiosity of workers who are laid off.

\section{Table 3. Paired Sample Test}

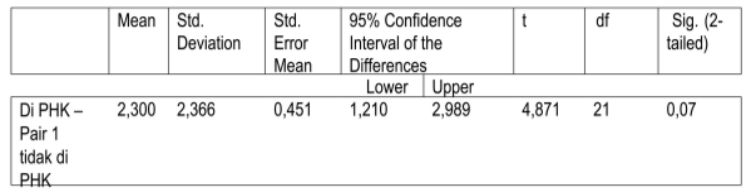

Paired Sample Test is a test aimed at comparing the level of religiosity between workers who have been laid off and workers who have not been laid off. Based on table 3 which is the result of the Paired Simple Test, it is known that the tcount value is 4.871 with a probability or significance $>0.05$. These results indicate that there is a difference in the level of religiosity between workers who are laid off and workers who are not laid off.

Differences in the level of religiosity of workers who are laid off and workers who are not laid off

\section{Table 4. Variable Y1 dan Y2}

\begin{tabular}{|c|c|c|c|c|c|c|}
\hline & & $\begin{array}{l}\text { Sum of } \\
\text { Squares }\end{array}$ & df & Mean Square & F & Sig. \\
\hline Y1 & $\begin{array}{c}\text { Between } \\
\text { Groups } \\
\text { Within } \\
\text { Groups } \\
\text { Total }\end{array}$ & $\begin{array}{r}2888.433 \\
710.500 \\
3598.933\end{array}$ & $\begin{array}{r}8 \\
6 \\
14\end{array}$ & $\begin{array}{l}361.054 \\
118.417\end{array}$ & 3.049 & .096 \\
\hline Y2 & $\begin{array}{c}\text { Between } \\
\text { Groups } \\
\text { Within } \\
\text { Groups } \\
\text { Total }\end{array}$ & $\begin{array}{l}1615.900 \\
2063.833 \\
3679.733\end{array}$ & $\begin{array}{r}8 \\
6 \\
14\end{array}$ & $\begin{array}{l}201.987 \\
343.972\end{array}$ & .587 & .762 \\
\hline
\end{tabular}


Table 4 is the result of the ANOVA test between the variable Y1 (workers who were laid off) and the variable Y2 (workers who were not laid off). In which the table states that the level of religiosity of workers who are not laid off is higher than that of workers who are laid off.

Religiosity is the quality of a person's appreciation in religion, where religion is used as a behavioral guide, so that his behavior is always oriented to the values he believes in. Based on the thoughts that have been described, both on the theoretical basis and in the field, it can be concluded that the factors that affect the level of religiosity of workers who have been laid off due to Covid-19 can be categorized as follows.

\section{Ideological}

Ideology or a belief in humans. It can be seen that the workers have their own level of belief in the teachings of their religion from the time they were born. Although not all workers have strong beliefs in the teachings of their respective religions. However, there are still workers who are diligent in carrying out religious activities on a daily basis.

\section{Ritualistic}

Ritual or worship is a person's level of obedience that is shown physically, such as prayer, zakat, sadaqah, and fasting. Based on the results of research that has been carried out on workers, it shows that $70 \%$ of workers perform worship according to religious teachings. Meanwhile, $30 \%$ of the workers still do not perform this physical worship regularly.

\section{Expressive Factor}

The expressive factor is the level of humans in feeling or experiencing religious things, such as being afraid of doing God's prohibition because their feelings are always aware of God's presence, and feelings when praying will always be granted. Based on the research conducted, it shows that $70 \%$ of the workers have not felt or have not had a religious experience, so that workers rarely express themselves to God. Where they sometimes often do things that are forbidden by Allah, and rarely pray or give thanks when they get pleasure. However, when they are in a slump they will begin to return to Allah, and ask Him a lot.

\section{Consequential}

Consequential is a factor of deeds, a person's level in daily behavior. Which behavior in question is more dominant in worldly behavior, how does it behave in the world. Based on the results of the research that has been done, it can be seen that $80 \%$ of the workers have behaved well in their daily lives. Such as visiting friends or relatives without being asked or invited 
and behave well to fellow friends and relatives.

\section{CONCLUSION}

The Covid-19 virus has become a pandemic whose impact is felt in almost every aspect and field of life. Among the impacts are on the economic and religious fields. Many of the workers had to lose their jobs, either because of unilateral layoffs or being laid off. Losing their status as workers makes the workers have no income to sustain their lives. Laid-off workers experience various difficulties in meeting the necessities of life. The difficulty of getting a new job in the midst of a pandemic outbreak is not in line with the increasingly high demands of life. However, the impact of the Covid-19 has turned out to have an effect on the religious side, both for workers who have been laid off and those who have not.

The impact of the Covid-19 pandemic on the level of religiosity is influenced by several factors, including ideological factors. , since they were born. Although not all workers have strong beliefs in their respective religious beliefs, there are still workers who are diligent in performing worship. These activities are activities that are directly related to the Almighty.

Ritualistic factors, which can be seen and shown physically, specifically, are a form of human level in feeling or experiencing the level of religiosity. It can be a feeling of fear when carrying out His prohibition because of the conscious behavior of His presence, as well as a feeling that when praying will be granted, based on research shows $70 \%$ of workers worship according to religious teachings, $30 \%$ still do not perform this physical worship regularly. Expressional factor, is a form of human level in feeling religious things. There is a feeling of fear when doing His prohibition, and having a sense of being aware of His presence. The results showed as many as $70 \%$ of workers still have not had a religious experience.

Consequential factor, is a form of action factor, namely the level of a person in his daily behavior. Behavior that leads to the behavior of the world. The results of the study as many as $80 \%$ of the workers have behaved well in their daily lives. It can be in the form of visiting friends when sick or relatives without being asked and behaving well towards fellow human beings.

\section{REFERENCES}

Anwar, Mohamad. (2020). "Dilema PHK dan Potong Gaji Pekerja di Tengah Covid-19". ADALAH (Buletin Hukum \& Keadilan), Vol. 4, No. 1, pp. $173-178$

BPSKabupatenJepara. (2020). Perusahaan Industri. https://jeparakab.bps.go.id/subject/9/ 
01--industri.html, (diakses pada 5 November 2020)

Fatwa Majelis Ulama Indonesia Nomor 14 Tahun $2020 \quad$ Tentang Penyelenggaraan Ibadah pada Situasi Terjadinya Pandemi Covid-19

Fitri, A. Z., \& Haryati, N. (2020). Metodologi Penelitian Pendidikan. Malang: Madani Media.

Hamali, S. (2001). Psikologi Agama, Terapi Agama Terhadap Problematika Psikis Manusia. AlAdYaN.

Kompas.com. (2020). Jokowi: Kerja dari Rumah, Belajar dari Rumah, Ibadah di Rumah Perlu Digencarkan. https://nasional.kompas.com/read/20 20/03/16/15454571/jokowi-kerjadari-rumah-belajar-dari-rumahibadah-di-rumah-perludigencarkan?page $=$ all, , (diakses pada 21 Oktober 2020)

Prajnaparamitha, Kanyaka \& Mahendra Ridwanul Ghoni. (2020). "Perlindungan Status Kerja Dan Pengupahan Tenaga Kerja Dalam Situasi Pandemi COVID-19 Berdasarkan Perspektif Pembaharuan Hukum". Administrative Law \& Governance, Volume 3, Issue 2, pp. 314-328.

Romlah, Siti. (2020). "Covid-19 dan Dampaknya Terhadap Buruh di Indonesia". ADALAH (Buletin Hukum \& Keadilan), Vol. 4, No. 1, pp. 213-222.

Rumah Sosiologi.com. (2020).Agama dan Ekonomi di Tengah Pandemi Covid19.

https://rumahsosiologi.com/tulisan/a rtikellepas/173-agama-dan-ekonomiditengah-pandemi-covid-19-pub, (diakses pada 21 Oktober 2020)

Sugiyanto, dkk. (2020). "Positive Value Of Covid 19 Pandemic For Msmes:A Case Study In Yogyakarta”. International Journal of Economics, Business and Accounting Research
(IJEBAR), Vol-4, Issue-3, pp. 229241

UU Nomor 13 Tahun 2003 Pasal 151 ayat

(1) tentang Ketenagakerjaan

World Health Organization. (2020). Coronavirus Disease (Covid-19) Situation,. https://www.who.int/ , (diakses pada 21 Oktober 2020). 